\section{Immunolocalization of ricin accumulation during castor bean (Ricinus communis L.) seed development}

\author{
Aisy Botega Baldoni, ${ }^{1,2}$ \\ Ana Cláudia G. Araújo,' Mayara Holanda \\ de Carvalho, ' Ana Cristina M. M. Gomes, ${ }^{1}$ \\ Francisco J.L. Aragão ${ }^{1,2}$ \\ 'Embrapa Recursos Genéticos e \\ Biotecnologia, Brasília; \\ ${ }^{2}$ Universidade de Brasília, Departamento \\ de Biologia Celular, Brasília, DF, Brazil
}

\section{Abstract}

Ricin is a dimeric glycoprotein that accumulates in protein storage vacuoles of endosperm cells of Ricinus communis L. (castor bean). The proricin travels through the Golgi apparatus and co-localizes throughout its route to the storage vacuoles of developing castor bean endosperm. We report here the pattern of seed morphological and ultrastructural changes during various stages of seed development, associated with ricin accumulation. ELISA was used to compare the ricin content in mature seeds of four Brazilian commercial cultivars. ELISA and immunoelectron microscopy analysis were used to study ricin accumulation during seed development from 10 to 60 days after pollination (DAP). Results have shown that no ricin could be localized in the endosperm cells in the early development stages (before $20 \mathrm{DAP}$ ) and only a few localization points could be observed at 30 DAP. However, a significant ricin localization signal was observed at $40 \mathrm{DAP}$ in the matrix of the protein storage vacuoles. The signal increased significantly from 50 to $60 \mathrm{DAP}$, when ricin was observed in both the matrix and crystalloids of the protein storage vacuoles. Understanding ricin expression at the cellular level is fundamental for the development of strategies for gene suppression using molecular breeding approaches.

\section{Introduction}

Castor bean (Ricinus communis L.) seeds contain approximately $50 \%$ of an oil with unique characteristics such as high viscosity, heat and pressure stability, low freezing point, and the ability to form waxy substances after chemical treatments. Consequently, this oil has many important industrial applications, such as in the production of lubricants, biodiesel, and plastics. ${ }^{1}$ Developing castor bean seeds accumulate lipids and storage proteins in their endosperm. In developing endosperm cells, the major storage proteins $7 \mathrm{~S}$ lectins [ricin and its homologue $R$. communis agglutinin (RCA), which share a high similarity], $2 \mathrm{~S}$ albumins, and $11 \mathrm{~S}$ globulins are accumulated in protein storage vacuoles. ${ }^{2,3}$ Castor bean cultivation and processing result in exposure to the potent toxin ricin, which is a dimeric glycoprotein composed of a toxic Achain (RTA) and a lectin B-chain (RTB) that are linked via disulfide bonds. ${ }^{4}$ The A-chain is a ribosome-inactivating enzyme that depurinates a specific adenine residue on the $28 \mathrm{~S}$ ribosomal RNA from animal cells. This activity prevents the formation of a critical stem-loop configuration, to which elongation factor 2 is known to bind during the translocation step of translation. It provokes cell death by inhibiting protein synthesis. ${ }^{5,6}$ The $\beta$-chain, which contains two galactose binding sites, binds specifically to cell surface glycoproteins or glycolipids and facilitates the movement of the Achain into cells. ${ }^{7}$ Extremely low levels of ricin are able to inhibit protein synthesis. According to Olsnes et al. ${ }^{8}$ only one A-chain molecule of ricin is able to irreversibly inactivate 2000 ribosomes/min. In addition, Eiklid et al. ${ }^{9}$ concluded that penetration of a single ricin molecule into the cytosol is enough to kill a mammalian (HeLa) cell. The estimated lethal ricin dose in humans is $1-10 \mu \mathrm{g} / \mathrm{kg}^{6,10}$

Ricin is synthesized as preproprotein (64.1 $\mathrm{kDa}$ ) in developing castor bean seeds. ${ }^{4}$ It is inserted into the lumen of the endoplasmic reticulum (ER), when the signal peptide is removed forming the proricin $(61.6 \mathrm{kDa})$. In the ER an intramolecular disulfide bond between the A and B subunits is formed, holding together the mature heterodimer. After a subsequent removal of the propeptides by a vacuolar protease, the mature dimer of 58.8 $\mathrm{kDa}$ is generated. ${ }^{4}$ Ricin is assumed to serve as a seed storage protein providing nutrients for seed germination and also may act as a defense protein. ${ }^{2,11,12}$ However, the environ mental role and evolutionary aspects of ricin accumulation in castor bean seeds still are not completely clarified.

Immunoelectron microscopy and cell fractionation reveal that proricin travels through the Golgi apparatus and co-localizes throughout its route to the storage vacuoles of developing castor bean endosperm. ${ }^{3}$ The ricin gene (coding for the ricin preproprotein) expression studied by RT-PCR and Northern analysis revealed that its expression increased significantly in seeds at 26-30 DAP, and the upward trend continued into later stages until 54-60 DAP. ${ }^{13,14}$ Using a radial immunodiffusion assay based on ricin-specific antibodies, ricin amount was quantified in accessions from the USDA castor collections, showing an extreme-
Correspondence: Francisco J. L. Aragão, Embrapa Recursos Genéticos e Biotecnologia, PqEB W5 Norte, 70770-917, Brasília, DF, Brazil.

E-mail: aragao@cenargen.embrapa.br

Key words: electron microscopy, endosperm, immunolocalization, protein bodies, seed development.

Acknowledgements: the authors wish to thank Dr. Máira Milani (Embrapa Algodão) for providing castor bean germplasm, and Prof. Sônia Báo (University of Brasília) for providing the facilities for electron microscopy. The research was supported by a grant from the Conselho Nacional de Desenvolvimento Científico e Tecnológico (CNPq, Brazil). ABB was supported by a fellowship from $\mathrm{CNPq}$.

Contributions: ABB carried out the practical work and wrote the paper; ACGA and ACMMG carried out the electron microscopic work; MHC helped in collecting the plant material, and with electron microscopy; FJLA the research group leader, analyzed the data and finalized the manuscript.

Conflict of interest: the authors report no conflicts of interest.

Received for publication: 30 April 2010.

Revision received: 14 June 2010.

Accepted for publication: 15 June 2010.

This work is licensed under a Creative Commons Attribution 3.0 License (by-nc 3.0).

(C) Copyright A.B. Baldoni et al., 2010

Licensee PAGEPress, Italy

International Journal of Plant Biology 2010; 1:e12 doi:10.4081/pb.2010.e12

ly wide range and differing significantly in ricin plus Ricinus communis agglutinin (RCA)

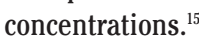

Ricin has been studied extensively in both medical and basic research since its discovery in the 1880 s. It has been used to investigate molecular mechanisms involved in intracellular trafficking and studied for its potential for therapeutic use in cancer chemotherapy. ${ }^{6,16}$ However, there is still limited information on ricin accumulation and genetic diversity in castor beans. There are studies on cell ultrastructure of mature and germinating seeds but detailed analysis during endosperm cell development is rare. In order to characterize ricin further, immunological techniques were used to localize protein expression in endosperm cells from developing castor bean seeds. Sections of developing castor bean seeds from six stages of development were used to characterize early ricin expression. We report here the pattern of seed morphological and ultrastructural changes during various stages of seed development, associated with ricin accu- 
mulation. This information could contribute to the genetic manipulation of ricin gene expression in castor bean seeds.

\section{Materials and Methods}

\section{Plant material}

Seeds from castor bean plant cvs. Energia, Nordestina, Pioneira, and Paraguaçu were used for ricin content determination. Plants from cv. Energia were grown from seed in a greenhouse at Embrapa Recursos Genéticos e Biotecnologia (Brasília, DF, Brazil) under ambient conditions. Initial flowering occurred approximately 60 days after sowing. Fully opened female flowers were tagged individually and hand pollinated, and the tagging dates recorded as days after pollination (DAP). Capsules were harvested at 10-day intervals to a maximum of 60 DAP. All collected capsules were analyzed anatomically. Seed coat, caruncle, nucellus, and endosperm were separated using a scalpel and razor blade.

\section{Quantification of ricin content}

Quantification of ricin content was carried out in the cvs. Energia, Nordestina, Pioneira, and Paraguaçu using ELISA. The cv. Energia was chosen for the analyses of ricin accumulation during seed development. Protein extraction was performed by mixing the seed powder $(0.2 \mathrm{~g})$ and $600 \mu \mathrm{L}$ of sample buffer $(50 \mathrm{mM}$ $\mathrm{NaH}_{2} \mathrm{PO}_{4}, 20 \mathrm{mM} \mathrm{NaCl}, 2 \mathrm{mM}$ PMSF, $10 \mathrm{mM}$ DTT, pH 7.0) for $30 \mathrm{~min}$ at $4^{\circ} \mathrm{C}$. The mixture was centrifuged $(18,500 \mathrm{~g})$ for $40 \mathrm{~min}$ at $4^{\circ} \mathrm{C}$ and the supernatant collected. Total protein was quantified using the Quick Start Bradford Protein Assay (Bio-Rad Laboratories, Inc., Hercules, CA, USA). Polystyrene 96-well plates were coated with $3 \mu \mathrm{g}$ total protein (diluted in PBS) and incubated for $4 \mathrm{hr}$ at $37^{\circ} \mathrm{C}$. The plates were washed three times with PBS, blocked with $200 \mu \mathrm{L} /$ well of block solution (PBS, Tween $(0.05 \%)$, and $2 \%$ defatted powdered milk) for $16 \mathrm{hr}$ at $4^{\circ} \mathrm{C}$. The plates were washed three times with block solution and incubated with specific goat anti-RTA antiserum (rcG-20; Santa Cruz Biotechnology Inc.) diluted in block solution $(1: 2,000)$ for $2 \mathrm{hr}$ at $37^{\circ} \mathrm{C}$. The rcG-20 is an affinity purified goat polyclonal antibody raised against a peptide mapping at the $\mathrm{N}$ terminus of the ricin precursor of $R$. communis origin. Although Western blot analysis showed that proricin precursor and glycoforms of ricin A-chain were recognized specifically, we could not exclude the possibility that the antibody would also detect the homologous RCA Achain, GenBank accession number P06750. The plates were washed seven times with block solution and incubated with $50 \mu \mathrm{L} /$ well of diluted secondary antibody (1:3000, rabbit anti-goat
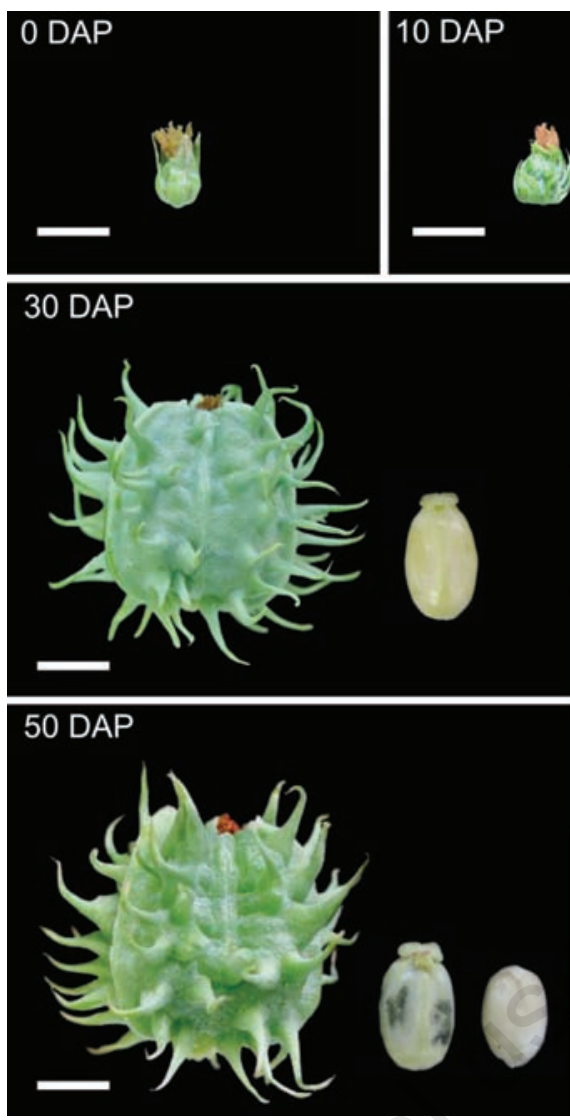
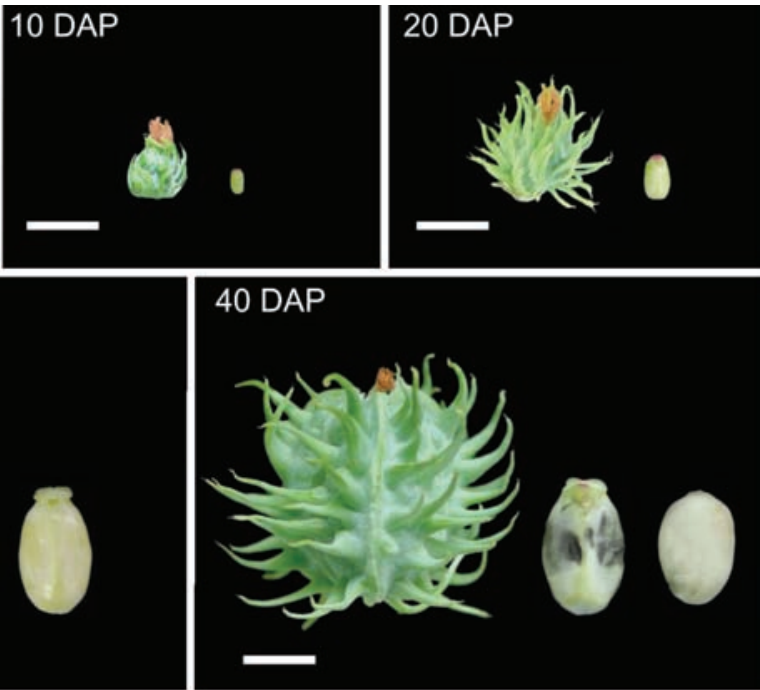

60 DAP

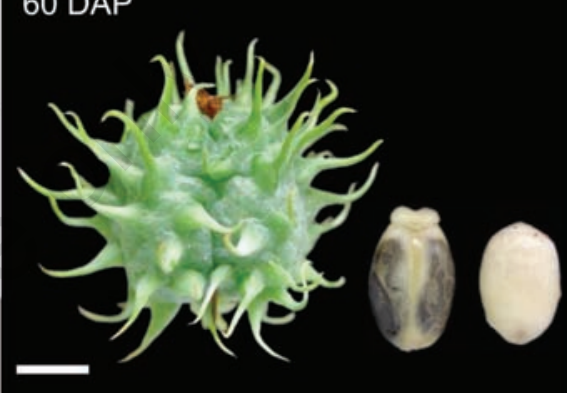

Figure 1. The morphological changes in castor bean seeds cv. Energia during development from: flower (0 DAP), fruits (on the left, 10 to $60 \mathrm{DAP}$ ), coated seeds (on the right, 10 to $30 \mathrm{DAP}$; in the middle, 40 to $60 \mathrm{DAP}$ ), and seeds without a coat (on the right, 40 to 60 DAP). DAP, days after pollination. Scale bars represent $1 \mathrm{~cm}$.

IgG conjugated with alkaline phosphatase, Santa Cruz Biotechnology Inc.) for $2 \mathrm{hr}$ at $37^{\circ} \mathrm{C}$. The plates were washed five times with PBS and the reaction was performed using the Alkaline Phosphatase Substrate Kit (Bio-Rad) according to the manufacturer's instructions. A standard curve was prepared using the purified ricin A (Sigma). Absorbance was measured in a microplate reader (Bio-Rad) at 405 $\mathrm{nm}$. Experiments were repeated with three biological and three technical replicates.

\section{Morphological and ultrastructural immunocytochemistry analyses}

Flowers were collected at each stage of seed development (10, 20, 30, 40, 50, and 60 DAP; Figure 1) and images of developing fruits were obtained. Samples were dissected and sectioned transversally and longitudinally. The fragments were immersed in the fixative solution of cacodilate buffer $0.05 \mathrm{M}$, pH 7.0 containing $2 \%$ paraformaldehyde and $0.2 \%$ glutaraldehyde for $24 \mathrm{hr}$ at $4{ }^{\circ} \mathrm{C}$, and subsequently dehydrated in an increasing series of ethanol solutions $(30 \%, 50 \%, 70 \%, 90 \%, 100 \%)$, for $15 \mathrm{~min}$ in each solution. Samples were displaced in transparent microtubes containing the acrylic resin LR White (London Resin) for 6 days at $4^{\circ} \mathrm{C}$ and then cured at $4^{\circ} \mathrm{C}$ under UV light for 3 days. Ultra-thin sections ( $60 \mathrm{~nm}$ thick) were obtained using the ultramicrotome Leica Ultracut UCT and collected on 300 mesh copper grids recovered with Formvar film. Grids were incubated with a solution $1 \%$ of uranyl acetate and examined in a Jeol 1011 transmission electron microscope, operated at $60 \mathrm{kV}$.

For ultrastructural immunocytochemistry, grids containing ultra-thin sections were incubated with blocking solution (PBS 1X, $0.5 \%$ Tween $20,2.5 \%$ bovine serum albumin) and primary antibody (Ricin A, rcG-20; Santa Cruz Biotechnology Inc.) diluted 1:200 for $1 \mathrm{hr}$. After incubation with primary antibody, sections were washed with PBS $1 \mathrm{X}$ solution and then incubated with Protein A coupled with 20 $\mathrm{nm}$ gold particles (SPI Supplies) diluted 1:50. Sections, with no counterstaining, were examined in the transmission electron microscope. As a control, the incubation with primary antibody was omitted. Only representative images that were consistently observed in sections of three or more individual seeds from each developmental stage were selected for presentation. 


\section{Results}

An enzyme-linked immunosorbent assay was carried out to compare the ricin content in mature seeds of four Brazilian commercial varieties and to study ricin accumulation during seed development from 10 to 60 days after pollination (DAP). Figure 1 illustrates the morphology of a developing seed. Our results showed that the cvs. Paraguaçu and Pioneira exhibit about $24 \%$ of the ricin content of the cvs. Nordestina and Energia (Figure 2A). Thus, the cv. Energia was chosen for further studies of ricin localization during seed development. ELISA analysis revealed that ricin could be detected in the seeds (cv. Energia) only at 30 DAP, and a significant increase was observed from 30 to 40 DAP (4.2 fold), from 40 to 50 DAP (5.8 fold), and from 50-60 (1.4 fold) (Figure 2B).

Endosperm cells at the early developing stage (30 DAP) presented large vacuoles and other organelles such as ER, nuclei, and mitochondria (Figure 3A). At 40 DAP cells were still vacuolated (Figure $3 \mathrm{~B}$ ) and the development of other storage organelles, such as protein storage vacuoles and lipid bodies, was first observed in some cells (Figure 3C). Phytin globoid cavities were also observed (Figure 3BC). At 50 to 60 DAP the cytosol was not evident and the cellular space was filled by protein storage vacuoles and lipid bodies (Figure 3DF). At 50 DAP protein crystalloids could be observed inside the protein storage vacuoles, while in some cells the structure of the protein storage vacuoles still was not mature (Figure 3D). At 60 DAP the protein crystalloids were more evident (Figure $3 \mathrm{E}$ and $\mathrm{F}$ ).

No ricin could be localized in the endosperm cells in the early developing stages (before 20 DAP) and only a few points could be observed at 30 DAP (data not shown). A significant ricin localization signal was observed at 40 DAP in the matrix of the protein storage vacuoles (Figure 4A). A significant increase in the ricin localization signal was observed from 50 to 60 DAP, and ricin could be observed both in the matrix and crystalloids of the protein storage vacuoles (Figure 4B-D). No background localization was observed in the control sections incubated with only the secondary antibody.

\section{Discussion}

Using ultrastructural immunocytochemistry techniques, the presence and accumulation of ricin in the endospermatic cells of castor bean were characterized during seed development. Castor beans store lipids and proteins in a living endosperm, which is attached laterally to the cotyledons. The endosperm is essentially

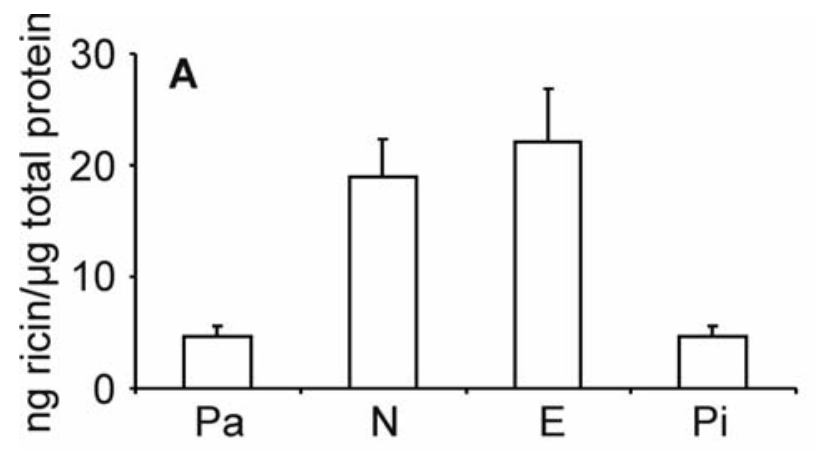

Figure 2. Ricin quantification in mature seeds of the cvs. Paraguaçu $(\mathbf{P a})$, Nordestina (N), Energia (E), and Pioneira (Pi) (A), and ricin accumulation in the cv. Energia during seed development (B). The numbers above each bar in (B) represent the mean. Error bars represent the standard deviation from the mean $(n=3)$.
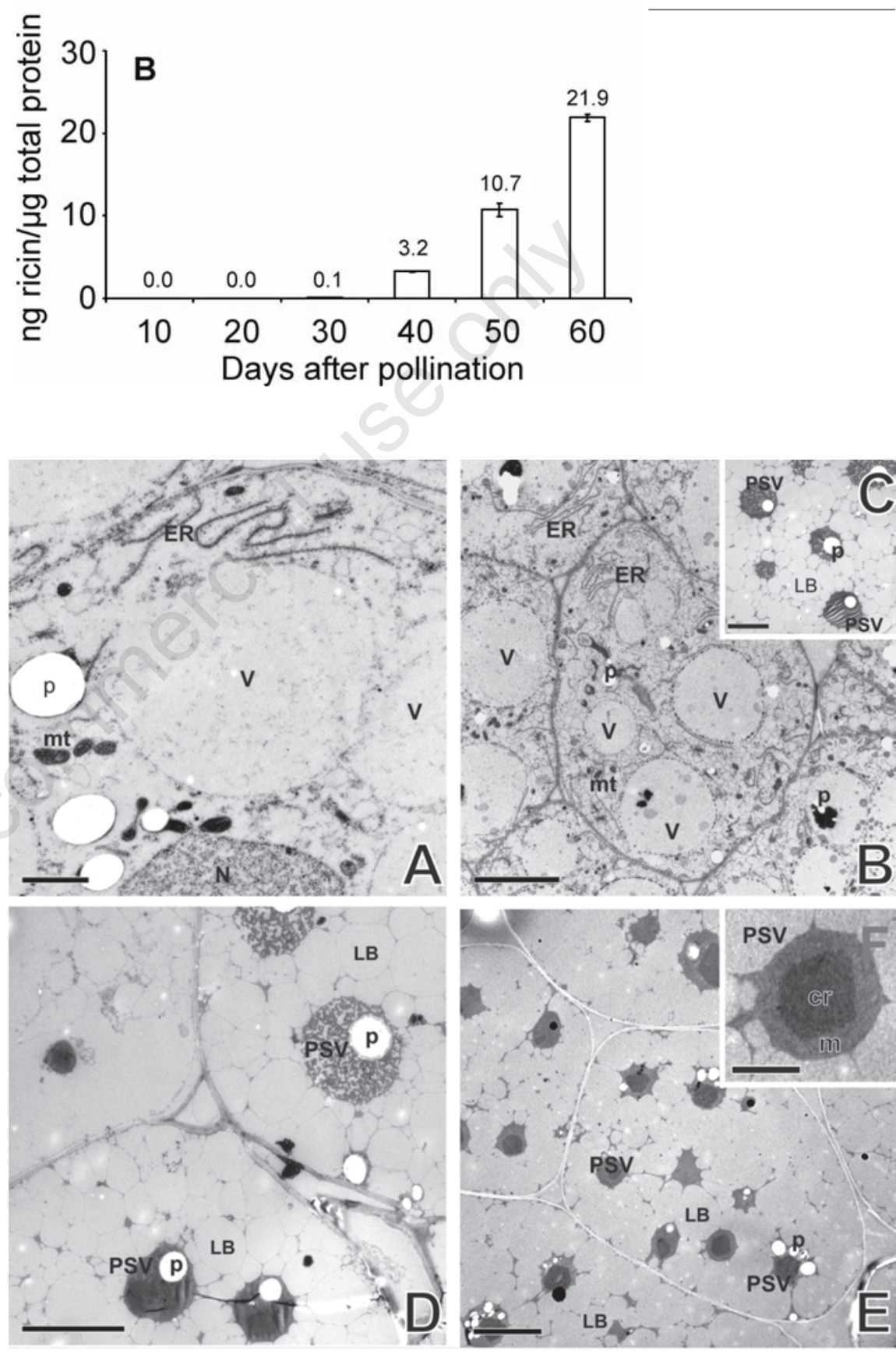

Figure 3. Endosperm cell development at 30 DAP (A), 40 DAP (B and C), 50 DAP (D), and $60 \mathrm{DAP}$ (D). RE, endoplasmic reticulum; V, vacuoles; mt, mitochondria; $N$, nucleus; PSV, protein storage vacuoles; LB, lipid bodies; p, phytin globoid cavities; cr, crystalloids; $\mathrm{m}$, matrix. DAP, days after pollination. Bars represent $2 \mu \mathrm{m}$ (in $\mathrm{A}$ and $\mathrm{C}$ ), $10 \mu \mathrm{m}$ (in B, $\mathrm{D}$, and $\mathrm{E}$ ) and $2.5 \mu \mathrm{m}$ (in the insert $\mathrm{F}$ ). 
free-nuclear in the early stages, at 5 to $10 \mathrm{DAP}$ (stages I and II according to Greenwood and Bewley $^{17}$ ), and it becomes primarily cellular by stage III (15 DAP). The transition from freenuclear to cellular endosperm (15 to 20 DAP) proceeds from the micropylar to the chalazal end of the seed. ${ }^{17}$ Our analyses confirmed previous observations: in the endosperm cells of mature castor bean most of the cell volume is filled with protein bodies and lipid bodies. ${ }^{18}$ In addition, we confirmed that formation of protein storage vacuoles started at about 40 DAP and only a number of cells exhibited that pattern, while others still presented an evident cytosol with ER and mitochondria (Figure 3). As expected, observations of protein and lipid bodies, and the pattern of phytin globoid formation, were consistent with the previous determinations of the amount of proteins, lipids, phytic acid, and phosphorous during the development of castor bean seeds. ${ }^{19}$

Previous analysis of proteins of endosperm sub-organelle fractions demonstrated that there was no overlapping of the protein components between the matrix and the crystalloids, suggesting a clear compartmentalization of the protein components within the protein bodies. ${ }^{18}$ In addition, it was established that the crystalloids are composed of storage protein of the globulin type, whereas the matrix contains non-storage albumin proteins, including ricin and phytohemagglutinin. ${ }^{18,20}$ In contrast, our results showed that ricin could be found in both matrix and crystalloid after 50 DAP (Figure 4B-D).

Ricin immunolocalization signal and accumulations during endosperm cell development were correlated with the development of endosperm. Our results were consistent with the previous observations on ricin gene transcription. Chen et al. ${ }^{14}$ used RT-PCR and Northern analysis to examine the transcription of the ricin gene during seed development and stated that no ricin $\mathrm{mRNA} / \mathrm{cDNA}$ was detected before the endosperm begins to develop (12 and 19 DAP). However, the expression increased significantly in 26-DAP seeds, and the upward trend continued into later stages until 54 DAP. Similar results were obtained by Kermode and Bewley, ${ }^{13}$ analyzing a ricin gene expression in developing endosperm at 30 to 60 DAP. In addition, Lu et al..$^{21}$ have shown that $1.5 \%$ of the ESTs derived from a full-length cDNA library of castor developing endosperm corresponded to the ricin gene. Taken together, these results corroborate the observation that ricin gene expression is spatially and temporally regulated.

Owing to its importance for industry and the possibility of using the remaining processed material as fertilizer or animal foodstuffs, there is considerable interest in reducing the ricin content in castor bean seeds using both classical and molecular breeding approaches.
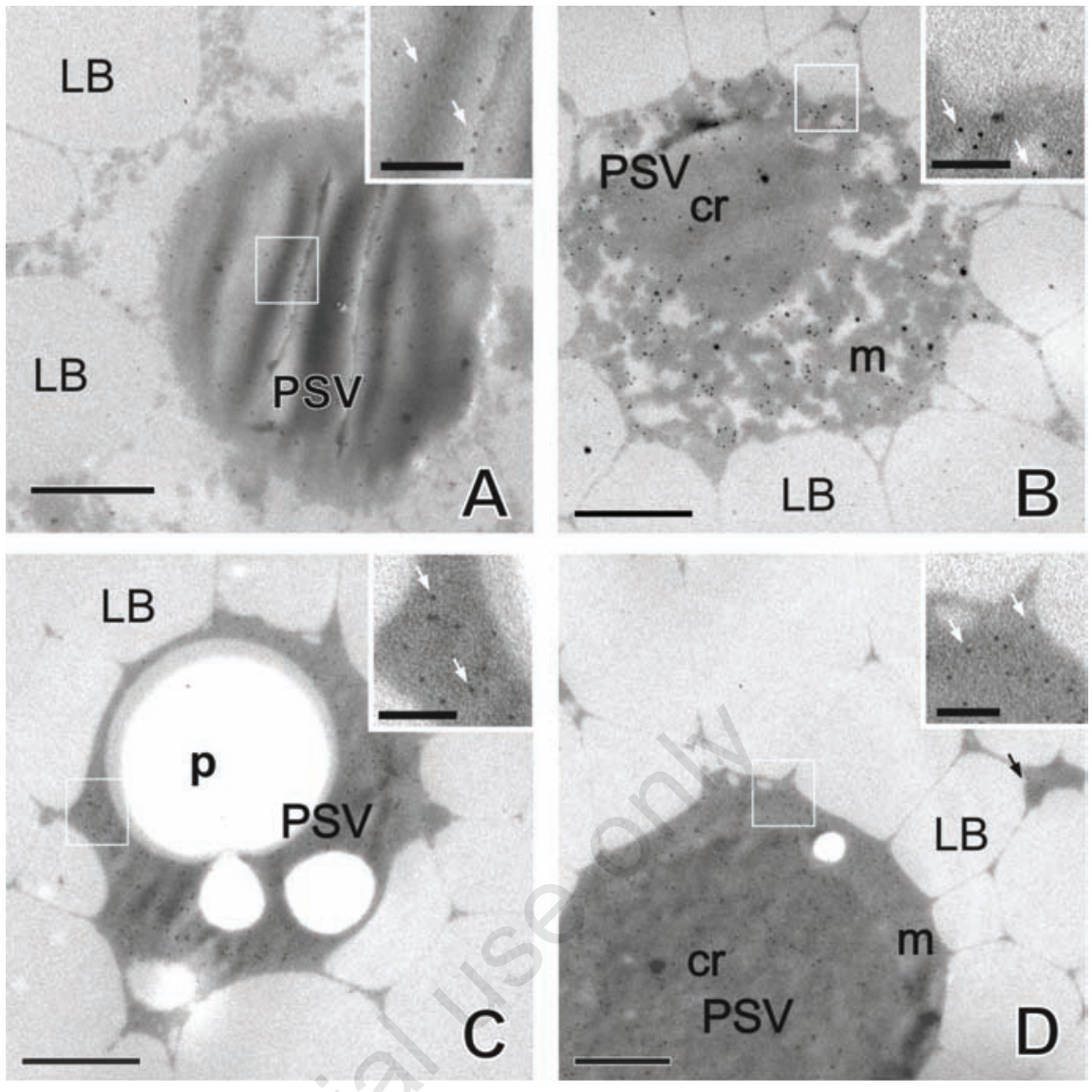

Figure 4. Immunolocalization of ricin in the endosperm cells during seed development at 40 DAP (A), 50 DAP (B), and 60 DAP (C and D). PSV, protein storage vacuoles; LB, lipid bodies; p, phytin globoid cavities; cr, cristalloids; $m$, matrix. DAP, days after pollination. Inserts show details of the area marked with the white boxes. Arrows in the inserts indicate the $20 \mathrm{~nm}$ gold particles localizing ricin. Bars represent $2.0 \mu \mathrm{m}$ (in A, B, C, and D) and $0.5 \mu \mathrm{m}$ (in the inserts).

Indeed, there are some recent examples in which expressing genes were knocked out. ${ }^{22-24}$ However, the understanding of protein expression at cellular level is fundamental for: i) development of constructs with regulatory sequences involving adequate temporal and spatial expression; ii) an effective method of screening individual mutants/transformants to block expression of ricin genes successfully; iii) biosafety analysis of transgenic events.

\section{References}

1. Godoy MG, Gutarra MLE, Maciel FM, et al. Use of a low-cost methodology for biodetoxification of castor bean waste and lipase production. Enzyme Microb Technol 2009;44:317-22.

2. Roberts LM, Lord JM. Protein biosynthetic capacity in the endosperm tissue of ripening castor bean seeds. Planta 1981;152: 420-7.
3. Jolliffe NA, Brown JC, Neumann U, et al. Transport of ricin and $2 \mathrm{~S}$ albumin precursors to the storage vacuoles of Ricinus communis endosperm involves the Golgi and VSR-like receptors. Plant J 2004;39: 821-33.

4. Maltman DJ, Gadd SM, Simon WJ, et al. Differential proteomic analysis of the endoplasmic reticulum from developing and germinating seeds of castor (Ricinus communis) identifies seed protein precursors as significant components of the endoplasmic reticulum. Proteomics 2007; 7:1-16.

5. Endo Y, Mitsui K, Motizuki M, et al. The mechanism of action of ricin and related toxic lectins on eukaryotic ribosomes. The site and the characteristics of the modification in $28 \mathrm{~S}$ ribosomal RNA caused by the toxins. J Biol Chem 1987;262:5908-12.

6. Audi J, Belson M, Patel M, et al. Ricin poisoning. A comprehensive review. JAMA 2005;294:2342-51.

7. Sphyris N, Lord JM, Wales R, et al. 
Mutational analysis of the Ricinus lectin B-chains. Galactose-binding ability of the 2 gamma subdomain of Ricinus communis agglutinin B-chain. J Biol Chem 1995;270: 20292-7.

8. Olsnes S, Fernandez-Puentes C, Carrasco $\mathrm{L}$, et al. Ribosome inactivation by the toxic lectins abrin and ricin. Kinetics of the enzymic activity of the toxin A-chains. Eur J Biochem 1975;60:281-8.

9. Eiklid K, Olsnes S, Pihl A. Entry of lethal doses of abrin, ricin and modeccin into the cytosol of HeLa cells. Exp Cell Res 1980; 126:321-6.

10. Rao PV, Jayaraj R, Bhaskar AS, et al. Mechanism of ricin-induced apoptosis in human cervical cancer cells. Biochem Pharmacol 2005;69:855-65.

11. Youle RJ, Huang AHC. Evidence that castor bean allergens are storage proteins in the protein bodies of castor bean. Plant Physiol 1978;61:1040-2.

12. Shewry PR, Napier JA, Tatham AS. Seed storage protein: structure and biosynthesis. Plant Cell 1995;7:945-56.

13. Kermode AR, Bewley JD. Developing seeds of Ricinus communis L., when detached and maintained in an atmosphere of high relative humidity, switch to a germinative mode without the requirement for complete desiccation. Plant Physiol 1989;90:702-7.

14. Chen GQ, He X, Mckeon TA. A simple and sensitive assay for distinguishing the expression of ricin and Ricinus communis agglutinin genes in developing castor seed (R. communis L.) J Agric Food Chem 2005; 53:2358-61.

15. Pinkerton SD, Rolfe R, Auld DL, et al. Selection of castor for divergent concentrations of ricin and Ricinus communis agglutinin. Crop Sci 1999;39:353-7.

16. Sandvig K, van Deurs B. Entry of ricin and Shiga toxin into cells: molecular mechanisms and medical perspectives. EMBO J 2000;19:5943-50.

17. Greenwood JS, Bewley JD. Seed development in Ricinus communis (castor bean). I. Descriptive morphology. Can J Bot 1982; 60:1751-60.

18. Youle RJ, Huang AHC. Protein bodies from the endosperm of castor bean. Subfractionation, protein components, lectins, and changes during germination. Plant Physiol 1976;58:703-9.

19. Greenwood JS, Gifford DJ, Bewley JD. Seed development in Ricinus communis cv. Hale (castor bean). II. Accumulation of phytic acid in the developing endosperm and embryo in relation to the deposition of lipid, protein, and phosphorus. Can J Bot 1984;62:255-61.

20. Tully RE, Beevers H. Protein bodies of castor bean endosperm: isolation, fractionation, and the characterization of protein components. Plant Physiol 1976;58:710-6.

21. Lu C, Wallis JG, BrowseJ. An analysis of expressed sequence tags of developing castor endosperm using a full-length cDNA library. BMC Plant Biol 2007;7:42.

22. Ogita S, Uefuji $\mathrm{H}$, Morimoto $\mathrm{M}$, et al. Application of RNAi to confirm theobromine as the major intermediate for efficient biosynthesis in coffee plants with potential for construction of decaffeinated varieties. Plant Mol Biol 2004;54:931-41.

23. Sunilkumar G, Campbell L, Puckhaber L, et al. Engineering cottonseed for use in human nutrition by tissue-specific reduction of toxic gossypol. Proc Natl Acad Sci USA 2006;103:18054-9.

24. Nunes ACS, Vianna GR, Cuneo F, et al. RNAi-mediated silencing of the myo-inositol-1-phosphate synthase gene (GmMIPS1) in transgenic soybean inhibited seed development and reduces phytate content. Planta 2006;224:125-32. 